American Journal of Environmental Sciences 5 (6): 714-721, 2009

ISSN 1553-345X

(C) 2009 Science Publications

\title{
Ecological Capability Assessment for Multiple-Use in Forest Areas Using GIS- Based Multiple Criteria Decision Making Approach
}

\author{
Sasan Babaie-Kafaky, Asadollah Mataji and Naser Ahmadi Sani \\ Department of Forestry, Science and Research Branch, Islamic Azad University, Tehran, Iran
}

\begin{abstract}
Problem statement: A valuable Source of plant and animal various species in the west of Iran is Zagros forests that, misuses by foresters and local societies has caused severe degradation. In this study, forest areas ecological assessment was carried out with a (GIS)-based MCDM approach for multiple-use planning in order to reduce degradation and improving sustainability. Approach: All of possible land uses were evaluated separately. The AHP was used to defining weight of criteria and sub-criteria. Sub-criteria were mapped at GIS environment using available data, fieldwork and IRSp6 data. A priority map for each land use was created using GIS-based WLC model. The final priority map was produced of overlying all priority maps. Ecological capability map were generated with editing priority map using present land use map, IRSp6 data, forest laws and fieldwork. Results: The Weights of criteria and sub- criteria was defined for all land uses with $\mathrm{CR}<0.10$. The most important criteria and sub-criteria for each land use were resulted, too. The final priority map was indicated preference of suitable land uses for each area, ecologically. The suitability map was showed areas that are enforceable land use together. Also, the area of each suitable land use was distinct. In more than of $70 \%$ study area, current use is not based on ecological criteria, which were caused severe degradation. Conclusion: The results of this study showed that various land uses meaning multiple-use can be exist in area study that executing of those will be cause decreasing of foresters dependence to forest trees, decreasing of degradation and forest sustainability. Thus, this integrated approach could be benefit forest planners and decision makers. Recommendation: Through this study, we aimed at suggesting to forest management and other stakeholders an approach that is scientifically sound and practical.
\end{abstract}

Key words: Zagros forests, multiple-use, MCDM, GIS, ecological capability

\section{INTRODUCTION}

An area about of 5-milion hectares, from northwest to southwest, has covered by Zagros forests that are one of the most important floristic zones in Iran. The main and dominant tree and shrub species are Persian oak (Qeurcus brantti), Qeurcus infectoria and Qeurcus libani. In this forests, so far away from the past, many of the incorrect use has caused severe degradation ${ }^{[20]}$ currently considered as degraded forests with firewood production and livestock feeding recognized as the main causes ${ }^{[47]}$. Although, this forests are national but foresters use incorrectly because, they are unemployment and very poor. Current uses of this forests area are firewood production, livestock feeding and agriculture. It is explicit that continuation of degradations and regardless to land suitability cause plenty multilateral damage for all beings. The traditional use of forests is multi-objective so that forests have been used for hunting, as a source of firewood and construction materials, for collection various non-wood products, protecting soil from erosion and regulate water resources. Some forests also have cultural and religious significance ${ }^{[41]}$. All of this uses there are in Zagros forests but regardless land capability. Recently, ecologically sustainable forestry has gained acceptance ${ }^{[42]}$. If the importance of the multiple-use of forests is not continuously recognized in forest management, there is a risk that the forests will lose many of the recreational and near-natural ecosystem characteristics ${ }^{[19]}$. Nowadays, forests are often managed for multiple uses. Forest planning is a very complex activity because there are many goals, which should be achieved simultaneously, and a lot of components and elements, which must be considered ${ }^{[4]}$. In planning forest ecosystem management, evaluations

Corresponding Author: Naser Ahmadi Sani, Department of Forestry, Islamic Azad University, Science and Research Branch, Tehran, Iran. 
of alternative plans with respect to ecological values are usually based on a set of variables describing the forest and the relationships between the variables and ecological values is assessed on the grounds of expert judgments ${ }^{[27]}$. Forest management policy decisions are complex due to the multiple-use nature of goods and services from forests, difficulty in monetary valuation of ecological services and the involvement of a large number of stakeholders ${ }^{[2]}$. In addition, other characteristics make natural resources decision-making situations complex. For example, group decision making and public participation are often required. To help decision makers make good choices, information and analyses are needed on the decision situation, on alternative of action, and on consequences of alternatives as well as on the preferences among these consequences. Because, decision results are very critical, thus choice of appropriate decision technique is necessary $^{[15]}$. The MCDM is an umbrella approach that has been applied to a wide range of natural resource management situations. From the overview and critical reviews of MCDM, it is clear that MCDM offers a suitable planning and decision-making framework for natural resources management and regional forest planning, because it is inherently robust and can accommodate conflicting, multidimensional, incommensurable and incomparable objectives ${ }^{[2,33]}$. Multiple Criteria Decision Support (MCDS) methods are decision analyses tools that have been developed for dealing with all that information in order to support complex decision making with multiple objectives ${ }^{[41]}$. As application of multi-criteria methods in natural resources and forestry studies with various abilities such as accommodating conflicting, multidimensional, incommensurable, incomparable objectives, formalizing public Participation in decision-making, increase the transparency and the credibility of the Process has been confirmed ${ }^{[1,3]}$. Thus, group decisionmaking and participation planning about multiple objective and multi-criteria evaluation and for forest planning and landscape ecological analyzes qualitative improvement is needed ${ }^{[23,33,41]}$. Potentiality integration of MCDM methods with GIS showed in various researches ${ }^{[8,21,24,26,33,34,37,39,43]}$. The GIS-based multicriteria decision-making approach is so simple and flexible that any number of criteria and indicators can be employed. Also GIS-based multi-criteria decisionmaking approach allows incorporation of decision makers, experts or other stakeholders into the forest conservation planning ${ }^{[39]}$. On the other hand, although with the fieldwork could be generated very precise data but often are difficult, time and cost consuming ${ }^{[29]}$. On the other hands, remote sensing data can apply as preparing tool some of ecological data and maps. For example spatial information and data estimation and mapping ${ }^{[6,25]}$, quantitative and qualitative assessment of ground resources ${ }^{[10,28]}$, suitability and change detection evaluation $^{[42,48,49]}$, criteria and indexes assessment in combination with GIS and fieldwork ${ }^{[14,39]}$. Thus, it is necessary to assessing ecological capability and land suitability using a GIS-based MCDM approach, in order to reduce of degradation, decreasing forester's dependence and Zagros forests sustainability applying multiple uses.

\section{MATERIAL AND METHODS}

Study area: The study area is about 10000 ha of Bane city forests, which is located in Iran, north part of Zagros mountainous forests (Fig. 1). The main species of these forests are $Q$. brantii, $Q$. infectoria and $Q$. libani that dominant species is $Q$. brranti. Although, this forests are national but, long term misuses from the past by foresters such as firewood production, livestock feeding and agriculture has caused severe degradation. At present, about $20 \%$ of the forest areas are forestland, 25\% agriculture and residential and $55 \%$ forest with crown cover less than of $50 \%$ (Fig. 2).

Executing methods: The possible land uses were distinguished. Criteria and sub-criteria influencing the suitability of land uses were selected by expert's judgment within AHP and reviewing relevant information from the literature $^{[5,9,11,17,18,30,32,35,36,38,40,50,53]}$. Sub-criteria were mapped using available maps and data, fieldwork, RS, GIS and various methods. The maps with the same properties in the whole study were not interference in analysis. Sub-criteria classified to indicators and then score of each class added to the attribute file according to expert's judgment and reviewing relevant information from the literature. The scores were ranged from 0-9 where a score of 0 and 1 meant constraint and equal importance, and where as 9 indicated extreme importance. All of criteria and sub-criteria for each land use were weighted using pairwise comparison by expert judgments within the analytical hierarchy process and the most important of criteria and sub-criteria for all land uses were determined. A set of questionnaires 
within the AHP framework was developed. In the questionnaire, respondents were determined relative importance of each criterion with respect to other, for example, importance of soil with respect to water, land cover and land unit. A priority map for each land use was created using GIS-based Weighted Linear Combination (WLC) model by MCE analyzes. The thresholds were generated by cluster analyze and resulted maps were classified. Then final priority map were produced of overlying all priority maps. Ecological suitability map were generated with editing priority map using current land use, water, density maps, satellite data and fieldwork.

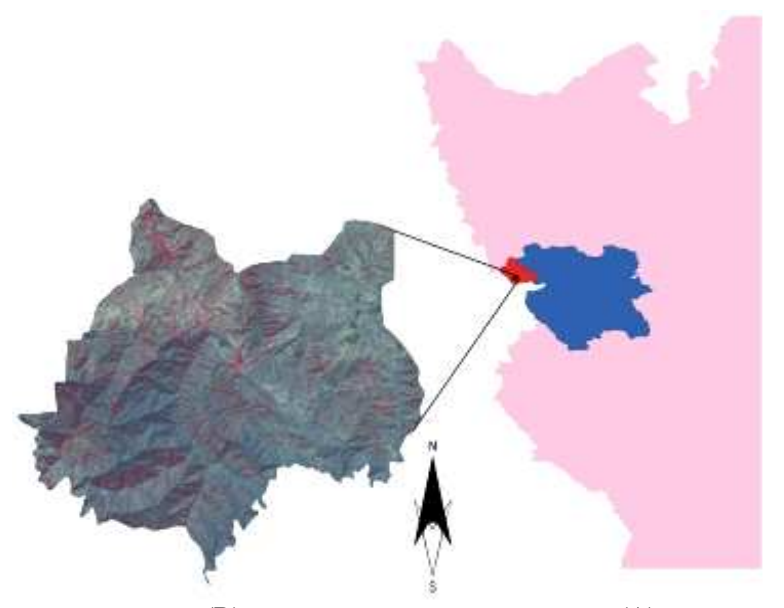

(B)

(A)

Fig. 1: (A) Study area location in Bane city, Kurdistan state, northwest of Iran. (B) IRSp6 image of study area (RGB)

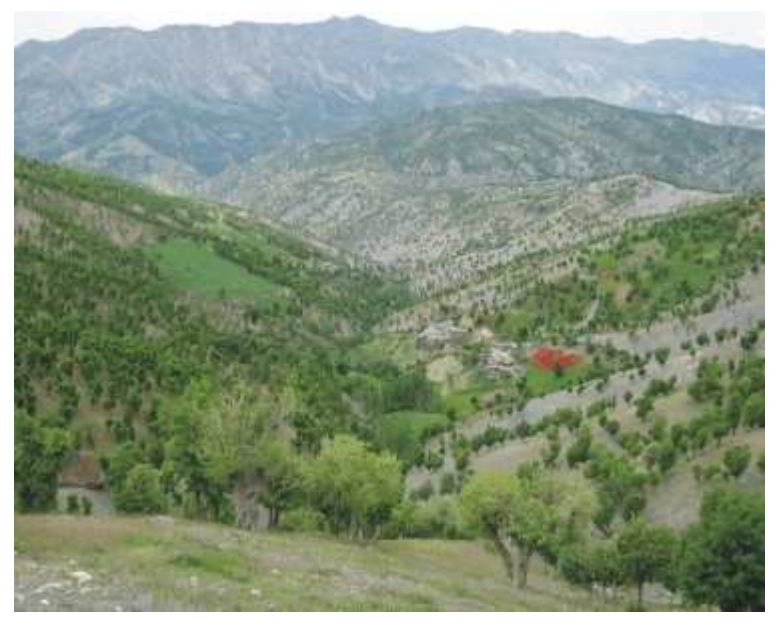

Fig. 2: A sight of study area

\section{RESULTS}

The distinguished possible land uses were forestry, range management, nature tourism, apiculture, pisciculture, dry farming, irrigated farming, horticulture and intensive husbandry. Table 1 shows the criteria and sub-criteria influencing the ecological suitability of land uses, too. Sub-criteria, indicators and their score map were created for all land uses. For example, Fig. 3 shows indicators (classified sub-criteria) maps of slope, forest density and their scored maps for dry farming land use.

The weights of criteria and sub- criteria were defined for all land use. The consistency ratio coefficients for final weights were fall in the acceptable range. For example, Fig. 4 and 5 show sub-criteria weight with $\mathrm{CR}<0.10$ for horticulture and forestry land uses. The most important criteria and sub-criteria for each land use were resulted, too (Table 2).

The suitability map that was created shows areas that are enforceable land use together. The priority map was created for all land use, separately.

For example Fig. 6 shows priority map of apiculture, nature tourism, forestry and dry farming. The resulted final priority map indicates preference of suitable land uses for each area, ecologically (Fig. 7). However, in three cases (Fig. 7), land uses could not be executed with together. Also, the area of each suitable land use was distinct (Table 3). So that Table 3 shows, in more than of $70 \%$ study area, current use is not based on ecological criteria, which were caused severe degradation. The finally, suitability map was generated that show areas that are enforceable land use together (Fig. 8).

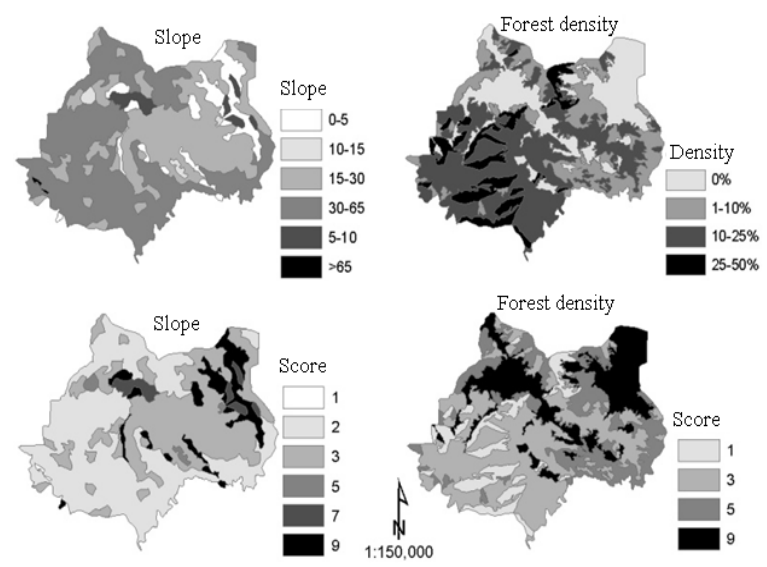

Fig. 3: Indicators map of slope and forest density and their score for dry farming 
Table 1: Source, mapping methods, scale and utilization of criteria and sub-criteria

\begin{tabular}{|c|c|c|c|}
\hline Criteria & Sub-criteria & $\begin{array}{l}\text { Source and mapping } \\
\text { methods }\end{array}$ & Scale and utilization \\
\hline Land cover & $\begin{array}{l}\text { Type } \\
\text { Forest density }\end{array}$ & $\begin{array}{l}\text { Sampling + visual interpretation of IRSp6 + current land use } \\
\text { Sampling + classification and IRSp6 interpretation + current land use }\end{array}$ & 1:25000, all land uses \\
\hline \multirow[t]{2}{*}{$\begin{array}{l}\text { Water } \\
\text { Resources }\end{array}$} & Quantity & $\begin{array}{l}\text { Current land use + interpretation IRSp6 + Water quantity of } \\
\text { springs and wells }\left(\mathrm{L} \mathrm{sec}^{-1}\right)\end{array}$ & $\begin{array}{l}\text { 1:50000, all land uses, except forestry } \\
\text { and dry farming }\end{array}$ \\
\hline & Quality & existing data & Same in whole study \\
\hline \multirow[t]{2}{*}{ Soil } & $\begin{array}{l}\text { Fertility } \\
\mathrm{Ph}\end{array}$ & $\begin{array}{l}\text { sampling + Geology map + land } \\
\text { type map + land cover } \\
\text { map + lab work }\end{array}$ & $\begin{array}{l}150000 \text {, all land uses, except pisciculture, } \\
\text { apiculture, intensive husbandry } \\
\text { 1:50000, all land uses, except pisciculture, } \\
\text { apiculture, intensive husbandry and nature } \\
\text { tourism }\end{array}$ \\
\hline & Erosion & Fieldwork + IRSp6 + existing data + created maps using FAO method & 1:50000, all land uses \\
\hline Landscape & Landscape & Fieldwork + hill shade + visual interpretation of IRSp6 + roads & $1: 50000$, nature tourism, only \\
\hline Climate & $\begin{array}{l}\text { Precipitation } \\
\text { Temperature }\end{array}$ & $\begin{array}{l}\text { Determining of equation using } \\
\text { neighbor meteorology stations + generalization using DEM }\end{array}$ & 1:50000, all land uses \\
\hline Land unit & $\begin{array}{l}\text { Slope } \\
\text { Elevation } \\
\text { Aspect }\end{array}$ & Using DEM & 1:50000, all land uses \\
\hline Geology & $\begin{array}{l}\text { Slide } \\
\text { Fault }\end{array}$ & Geology map & $1: 100000$, Non-existence in whole study \\
\hline \multicolumn{2}{|c|}{ Necessary maps other } & Source and mapping methods & Scale and utilization \\
\hline \multicolumn{2}{|c|}{ Current land use } & Ground truth with GPS + visual interpretation of IRSp6 & $1: 25000$, suitability mapping \\
\hline \multicolumn{2}{|l|}{ Land type } & Visual interpretation of IRSp6 + hill shade + slope and elevation map & 1:25000, soil parameters mapping \\
\hline \multicolumn{2}{|l|}{ Constrant1 } & Ground truth with GPS + sampling + visual interpretation of IRSp6 & 1:25000, all land uses, except Nature tourism \\
\hline \multicolumn{2}{|l|}{ Constrant2 } & Ground truth with GPS + sampling + visual interpretation of IRSp6 & $\begin{array}{l}\text { 1:25000, pisciculture, intensive husbandry, } \\
\text { irrigated farming and horticulture }\end{array}$ \\
\hline
\end{tabular}

Table 2: Most important criteria, sub-criteria and their weight for each land use resulted from AHP

\begin{tabular}{|c|c|c|c|c|c|c|c|c|c|}
\hline Land use & $\begin{array}{l}\text { Nature } \\
\text { tourism }\end{array}$ & Forestry & $\begin{array}{l}\text { Range } \\
\text { management }\end{array}$ & $\begin{array}{l}\text { API } \\
\text { culture }\end{array}$ & $\begin{array}{l}\text { Dry } \\
\text { farming }\end{array}$ & $\begin{array}{l}\text { Irrigated } \\
\text { farming }\end{array}$ & Pisciculture & Horticulture & $\begin{array}{l}\text { Intensive } \\
\text { husbandry }\end{array}$ \\
\hline $\begin{array}{l}\text { The most } \\
\text { criteria } \\
\text { important }\end{array}$ & $\begin{array}{l}\text { Water source } \\
\text { + landscape }\end{array}$ & $\begin{array}{l}\text { Climate }+ \\
\text { plant cover }\end{array}$ & $\begin{array}{l}\text { Water source }+ \\
\text { plant cover }\end{array}$ & $\begin{array}{l}\text { Plant } \\
\text { cover }\end{array}$ & Climate & $\begin{array}{l}\text { Water } \\
\text { source }\end{array}$ & $\begin{array}{l}\text { Water } \\
\text { source }\end{array}$ & $\begin{array}{l}\text { Water } \\
\text { source }\end{array}$ & $\begin{array}{l}\text { Water } \\
\text { source }\end{array}$ \\
\hline Weight & $0.279+c$ & $427+0.310$ & $0.302+0.285$ & & 0 & 0.393 & 0.5 & $0.362+0.315$ & 0.448 \\
\hline $\begin{array}{l}\text { The most } \\
\text { sub-criteria } \\
\text { important }\end{array}$ & $\begin{array}{l}\text { Water quantity } \\
+ \text { landscape }\end{array}$ & Density & $\begin{array}{l}\text { Water quantity } \\
+ \text { cover type }\end{array}$ & $\begin{array}{l}\text { Cover } \\
\text { type }\end{array}$ & Precipitation & $\begin{array}{l}\text { Water } \\
\text { quantity }\end{array}$ & $\begin{array}{l}\text { Water } \\
\text { quantity }\end{array}$ & $\begin{array}{l}\text { Water } \\
\text { quantity }\end{array}$ & $\begin{array}{l}\text { Water } \\
\text { quantity }\end{array}$ \\
\hline Weight & $0.206+0.160$ & 0.198 & $0.188+0.178$ & 0.24 & 0.298 & 0.234 & 0.394 & 0.2 & 0.31 \\
\hline
\end{tabular}

Table 3: area comparison of current land use and ecological suitable land use

\begin{tabular}{lllllllllll}
\hline Suitable land use & d-n-a & f-n-a & r-n-a & n & i-n-a & p-n & Ho-n-a & Ho-p-hu-n-a & Ho-p-i-hu-n-a & Ho-p-n-a \\
\hline Area (\%) & 12.5 & 57 & 14.25 & 2.5 & 3 & 0.5 & 1 & 1.75 & 7 & 0.5 \\
Current land use & d-i-hu-ho-r & f-r & fl-r & res-hu & - & - & - & - & - & - \\
Area (\%) & 23 & 54.7 & 20.5 & 1.8 & - & - & - & - & - & - \\
\hline
\end{tabular}

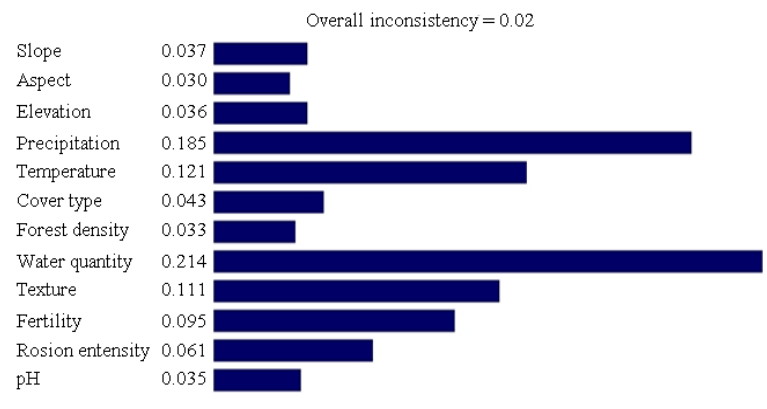

Fig. 4: Sub-criteria weight and overall inconsistency for horticulture land use

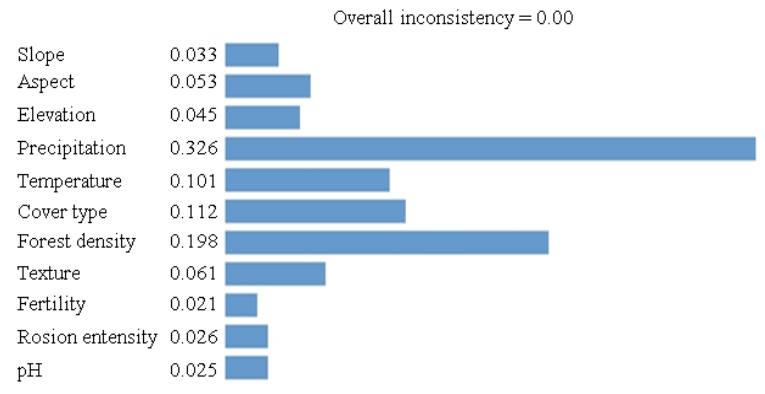

Fig. 5: Sub-criteria weight and overall inconsistency for forestry land use 

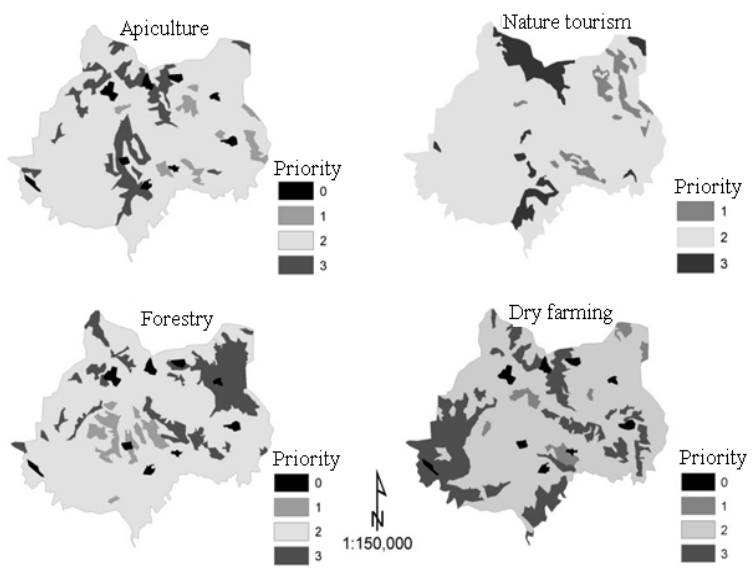

Fig. 6: Priority map of apiculture, nature tourism, forestry and dry farming

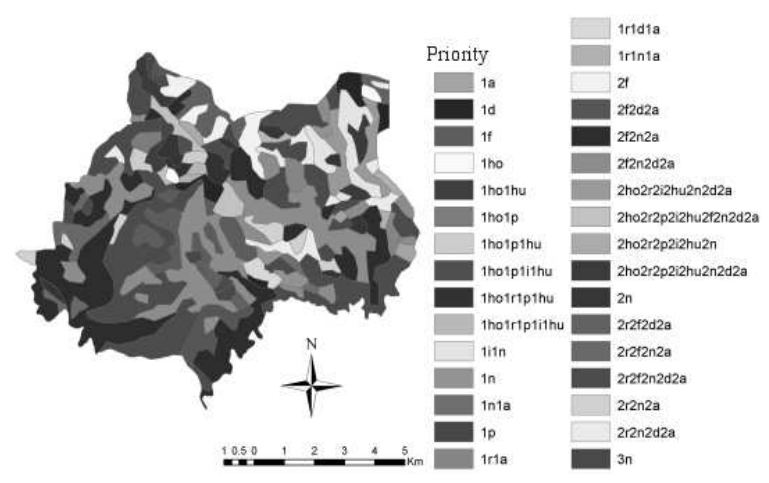

Fig. 7: Final priority map

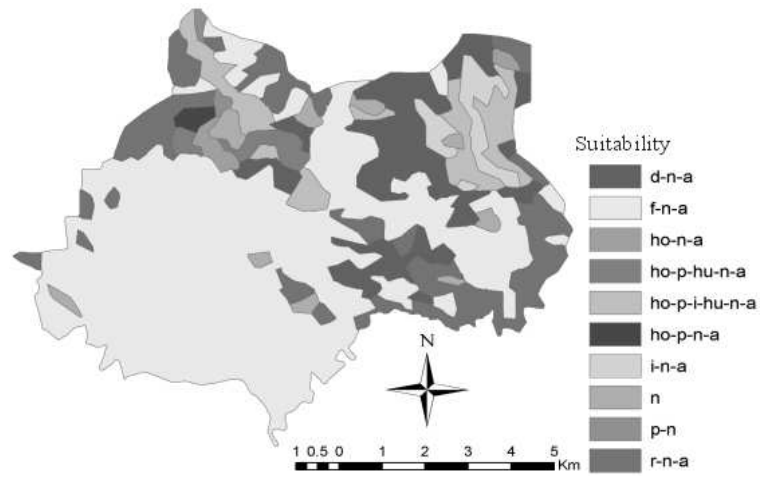

Fig. 8: Suitability map

\section{DISCUSSION}

The $\mathrm{AHP}^{[44,45,46]}$ is a known and common multiattribute weighting method for decision ${ }^{[12,13,16,51,52]}$. AHP is a comprehensive, logical and structural framework, which allows improving the understanding of complex decisions by decomposing the problem in a hierarchical structure. AHP allows the consistent comparison of both qualitative and quantitative criteria or alternatives, since different scales of input information are transformed to uni-dimensional priorities ${ }^{[54]}$. Use of AHP for assigning the weights of relative importance to the objectives is relatively new ${ }^{[52]}$. The use of AHP insures that the suitability maps are comparable for all land uses ${ }^{[31]}$. In this research, using AHP, consistent weight of all of criteria and sub- criteria for all land use, through pairwise comparison was evaluated, properly and confirmed result of previous studies in related with AHP. In addition, within AHP the criteria and sub-criteria influencing the ecological suitability of land uses were defined, properly and perfectly (Table 1). Although the $\mathrm{AHP}^{[45]}$ method is widely accepted in solving multicriterion problems, the accuracy of the results depends on accuracy of spatial data. Moreover, the selection of land suitability assessment parameters, priority weights within the AHP framework are greatly influenced by objectives, location, maps, people involved in discussions and key informants. In this research, AHP in combination with RS and GIS were three major tools in a manner that reached the correct solution to assist the decision maker in determining appropriate values for the ecological suitability criteria. A $\quad \mathrm{CR}<0.10$ indicates a reasonable level of consistency among pairwise comparisons ${ }^{[31]}$. In this study, consistency ratio coefficients for the final weightings were fall in the acceptable range (Fig. 3 and 4).

In similar with various studies ${ }^{[6,7,22]}$, GIS provided valuable information for spatial forestmanagement planning in adjacency, proximity and juxtaposition of patches. In addition to the refinement of compartment maps, GIS was also applied in managing and visualization of ecological data in different stages. Remote sensing techniques assessed the land use information cost effectively ${ }^{[49]}$. Remote sensing now a day has become a modern tool for mapping of land use/land cover for micro, meso and macro level planning ${ }^{[48]}$. In this research, the role of RS is much more apparent by setting out some of the new opportunities for RS data sources, analysis and applications to forest resource assessment (Fig. 3). As sub-criteria, indicators and their score map created with high precious at GIS environment using IRSp6 data and fieldwork for all land uses is showing of this roles. For example, Fig. 3 shows indicators (classified subcriteria) maps of slope, forest density and their scored maps for dry farming land use.

In addition to, so that Fig. 3 and 4 and Table 2 shows, similar to previous researches, weights of 
criteria and sub-criteria for each land use were resulted, properly. That shows efficiency of AHP for parameters preference determining in the same researches. The priority map that was generated indicates preference of suitable land use for each area, ecologically. The suitability map that was created shows areas that are enforceable land use together. However, in three cases (Fig. 7), land uses could not be executed with together thus; the best land use must be identified by economical studies in combination with the results of this study. So that table 3 shows, in more area of study area, current use of these forest areas is not based on ecological criteria, which were caused severe degradation. For example, although ecologically, in $14 \%$ of study area, range management and extensive husbandry is allowed but there is in more than of $95 \%$ study area. Thus, this integrated approach could be benefit forest planners and decision makers. If, the importance of the multiple-use of Zagros forests is not recognized in forest management, the forests will lose many of the recreational, natural ecosystem characteristics and countless values.

\section{CONCLUSION}

This study demonstrates the ecological assessment potentiality of multiple-use for forest planning, comprehensive sight of integrating quality of MCDM and GIS in the suitability assessment process, characteristics and tools. If, the importance of the multiple-use of Zagros forests is not recognized in forest management, the forests will lose many of the recreational, natural ecosystem characteristics and countless values. Thus, integration of GIS and MCDM could benefit forest planners and decision makers. This method also provides a cost effective, rapid land evaluation framework, which help policy makers, regional planners, forest manager and researchers working in developing countries. The results of this study show that various land uses can be exist in area study that executing of those will be cause decreasing of foresters dependence to forest trees, decreasing of degradation and forest sustainability. Consolidation of local people knowledge and expert's views with modern geographic techniques to evaluate the land uses was caused this research results more empirical and original. The results of this study are suggesting to forest managers and other stakeholders so approach that is scientifically complete, sound and practical.

\section{REFERENCES}

1. Anada, J. and G. Herath, 2003. The use of AHP to incorporate stakeholder preferences into regional forest planning. For. Policy Econ., 5: 13-26.
2. Anada, J. and G. Herath, 2008. Multi-attribute preference modeling and regional land-use planning. Ecologic. Econ., 65: 325-335. DOI: 10.1016/j.ecolecon.2007.06.024

3. Anada, J. and G. Herath, 2009. A critical review of multi-criteria decision-making methods with special reference to forest management and planning. Ecologic. Econ., 68: 2535-2548. DOI: 10.1016/j.ecolecon.2009.05.010

4. Anderle, C., M. Fedrizzi and S. Giove, 1994. Fuzzy multiple objective programming techniques in modeling forest planning. Proceedings of EUFIT'94 Conference, Verlag der Augustinus Buchhandlung, Aachen, Germany, pp: 1500-1503.

5. Barnes, B.V., D.R., Zak, S.R. Denton and S.H. Spurr, 1997. Forest Ecology. Wiley Publications, 4th Edn., New York, ISBN: 978-0-471-30822-5, pp: 792.

6. Baskent, E.Z. and S. Keles, 2005. Spatial forest planning: A review. Ecol. Model., 188: 145-173. DOI: 10.1016/j.ecolmodel.2005.01.059

7. Baskent, E.Z., S. Terzioglu and S. Baskaya, 2008. Developing and implementing multiple-use forest management planning in Turkey. Environ. Manage., 42: 37-48. DOI: 10.1007/s00267-0089106-6

8. Basnet, B., A.A. Apan and R. Raine, 2001. Selecting suitable sites for animal waste application using a raster GIS. Environ. Manage., 28: 519-531.

http://www.ncbi.nlm.nih.gov/pubmed/11494070

9. Bhattacharya, P. and S. Kumari, 2004. Application of criteria and indicator for sustainable ecotourism. Proceeding of the Bi-Annual Conference on the Commons in an Age of Global Transition: Challenges, Risk and Opportunities, Aug. 9-14, Oaxaca, Mexico.

http://dlc.dlib.indiana.edu/archive/00001343/00/Bh attacharya_Application_040511_Paper258.pdf

10. Birnie, R.V., M. Aitkenheade, P. Lumsdon, D.R. Miller and W. Towers et al., 2004. The changing role of remote sensing for land resource assessment in Scotland: Lessons for the future, mapping and resources management. Proceeding of the RSPSoc Annual Conference, (RAC'04), Macaulay Land Use Research Institute, pp: 35.

11. Elahi, Y., 2006. Systematic Apiculture. 1st Edn., Kavthar Institute Publications, Iran, p: 281.

12. Eldrandaly, K.H., N. Eldin, D. Sui, M. Shouman and G. Nawara, 2005. Integrating GIS and MCDM using COM technology. Int. Arab J. Inform. Technol., $\quad 2$ : 163. http://www.fci.zu.edu.eg/facultyandstaff/khpub\%5 CGIS-MCDM.pdf 
13. Forman, E.H. and M. Ann-Selly, 2002. Decision by Objectives. 1st Edn., World Scientific Publishing Co. Pte. Ltd., ISBN: 981-02-4142-9, pp: 422.

14. Geneletti, D. and I.V. Duren, 2008. Protected area zoning for conservation and use: A combination of spatial multi-criteria and multi-objective valuation. Landscape Urban Plann., 85: 97-110. DOI: 10.1016/j.landurbplan.2007.10.004

15. Ghodsi-Poor, H., 2009. Analytic Hierarchy Process. 7th Edn., Amir Kabir University Publications, Tehran, ISBN: 964-463-056-4, pp: 236.

16. Gonzalez, J.R., O. Kolehmainen and T. Pukkala, 2007. Using expert knowledge to model forest stand vulnerability to fire. Comput. Elect. Agric., 55: 107-114. DOI: 10.1016/j.compag.2006.12.005

17. Grigg, D., 1995. An Introduction to Agricultural Geography. 2nd Edn., Routledge Publications, pp: 240.

18. Jackson, D., 1999. Temperate and Subtropical Fruit Production. 2nd Edn., CABI Publications, pp: 352.

19. Hjorts, C.N. and S. Strade, 2001. Strategic multiple-use forest planning in Lithuania applying multi-criteria decision-making and scenario analysis for decision support in an economy in transition. For. Policy Econ., pp: 175-188. DOI: 10.1016/S1389-9341(01)00066-1

20. Jazeerie, M.H. and M. Ebrahimi-Rostaghi, 2003. Zagros Silviculture. Tehran University Publications, pp: 558.

21. Kangas, J., A. Kangas, P. Leskinen and J. Pykalainen, 2001. MCDM methods in strategic planning of forestry on state-owned lands in Finland. J. MultiCriteria Dec. Anal., 10: 257-271. DOI: 10.1002/mcda.306

22. Kangas, J., R. Store, P. Leskinen and L. Mehtatalo, 2000. Improving the quality of landscape ecological forest planning by utilizing advanced decision-support tools. Forestecol. Manage., 132: 157-171.

http://cat.inist.fr/?aModele=afficheN\&cpsidt=1427279

23. Kangas, J., R. Store and A. Kangas, 2005. Socioecological landscape planning approach and multicriteria acceptability analysis in multiplepurpose forest management. For. Policy Econ., 7: 603-614. DOI: 10.1016/j.forpol.2003.12.001

24. Karimi, V., H. Ebadi and S. Ahmadi, 2006. Public parking site selection using GIS. http://www.gisdevelopment.net/application/urban/o verview/mwf_112abs.htm

25. Lathrop, G.R., J.A. Bognar, 1998. Applying GIS and landscape ecological principles to evaluate land conservation alternatives. Landsci. Urban Plan., 41: 27-41. DOI: 10.1016/S01692046(98)00047-4
26. Lee, A.H. and D.S. Guttmann, 2004. Utilizing a geographic information system in conjunction with the analytical hierarchy process to perform a water reclamation plant site suitability analysis.

http://proceedings.esri.com/library/userconf/proc03 /p0829.pdf

27. Leskinen, P., J. Kangas and A.M. Pasanen, 2003. Assessing ecological values with dependent explanatory variables in multi-criteria forest ecosystem management. Ecol. Model., 170: 1-12. DOI: 10.1016/S0304-3800(03)00283-7

28. Mackay, D.S., S. Samanta, R.N. Ramakrishna, E.B. Lawrence, 2003. Multi-objective parameter estimation for simulating canopy transpiration in forested watersheds. J. Hydrol., 277: 230-247. DOI:10.1016/S0022-1694(03)00130-6

29. Makhdom, M., A.A. Darvish-sefat, H. Jaafar-zadeh and A. Makhdom, 2007. Environment Planning and Evaluation with Geographic Information System. 3rd Edn., Tehran University Publications, ISBN: 964-03-4474-5, pp: 304.

30. Makhdom, M., 2006. Fundamental of Land use Planning. 7th Edn., Tehran University Publications, ISBN: 964-03-4025-1, pp: 289.

31. Martins, H., J.G. Borges, 2007. Addressing collaborative planning methods and tools in forest management. For. Ecol. Manage., 248: 107-118. DOI: 10.1016/j.foreco.2007.02.039

32. Mazaheri, D. and N. Majnon-Hosieni, 2002. General Farming Bases. 1st Edn., Tehran University Publications, Iran, pp: 320.

33. Mendoza, G.A. and H. Martins, 2006. Multicriteria decision analysis in natural resource management: A critical review of methods and new modeling paradigms. For. Ecol. Manage., 230: 1-22. DOI: $10.1016 /$ j.foreco.2006.03.023

34. Mohd-Armi, A.S., A.M. Latifah, A.S. Wan-Nor and I. Rafiku, 2007. Application of AHP for selecting an appropriate solid waste treatment technology. Proceeding of the 2nd National Intelligent Systems and Information Technology Symposium, (ISITS'07), ITMA -UPM, Malaysia, pp: 127-146. http://www.env.upm.edu.my/env_en/publication_i nfo.jsp?id=413

35. Norman, M.J.T., C.J. Pearson and P.G.E. Searle, 1995. The Ecology of Tropical Food Crops. 2nd Edn., Cambridge University Press Publications, Cambridge, pp: 444.

36. Ok, K., 2006. Multiple criteria activity selection for ecotourism planning in Agenda. Turk. J. Agric., 30: 153-164.

http://journals.tubitak.gov.tr/agriculture/issues/tar06-30-2/tar-30-2-8-0502-12.pdf 
37. Parhizkar, A. and A. Ghafari-Gilandeh, 2001. Geographic Information System and Multi-Criteria Decision-Making. 1st Edn., Samt Publications, Tehran, pp: 597.

38. Porter-Bolland, L., 2001. Landscape ecology of apiculture in the Maya area of La Montana. Dissertation for Ph.D., Campeche, Mexico, University of Florida, pp: 196, http://etd.fcla.edu/UF/UFE0000343/master-1.PDF

39. Phua, M.H. and M. Minowa, 2005. A GIS-based multi-criteria decision making approach to forest conservation planning at a landscape scale: A case study in the Kinabalu Area. Sabah, Malay. Landscape Urban Plan., 71: 207-222. DOI: 10.1016/j.landurbplan.2004.03.004

40. Pir-Irani, E., 2005. Honeybees and Apiculture. Islamic Azad University Publications, Iran, pp: 638.

41. Pukkala, T., 2005. Multi-Objective forest planning. Manag. For. Ecosyst., 78: 457-458. http://forestry.oxfordjournals.org/cgi/reprint/78/4/4 57-a

42. Quan, B., H.J. Zhu, S.L. Chen, M.J.M. Romkens and L.B. Cheng, 2007. Land suitability assessment and land use change in Fujian province, China. Soil Sci. Soc. China, 17: 493-504. DOI: 10.1016/S1002-0160(07)60059-9

43. Rowbotham, D., 2007. Site suitability for landfills in the North Bay Ontario area, LIMANER Consultants Final Report, pp: 37. http://www.nipissingu.ca/faculty/davidr/GEOG405 7/TermPapers/Mar29/Site_Suitability_for_Landfill s_in_the_North_Bay_Ontario_Area.pdf

44. Saaty, T.L., 1980. The Analytic Hierarchy Process. Mc Graw Hill Inc., New York, ISBN: 0070543712 pp: 287.

45. Saaty, T.L., 1990. Multicriteria Decision Making: The Analytic Hierarchy Process. RWS Publications, Pittsburgh, ISBN: 10: 0962031720, pp: 437.

46. Saaty, T.L., 2008. Decision making with the analytic hierarchy process. Int. J. Serv. Sci., 1: 16. http://www.colorado.edu/geography/leyk/geog_51 13/readings/saaty_2008.pdf

47. Sagheb-Talebi K., T. Sajedi and F. Yazdian, 2004. Forests of Iran. Research Institute of Forests and Rangelands, Technical Publication, No. 339, pp: 56.

48. Srivastava, S.K. and R.D. Gupta, 2003. Monitoring of changes in land use/ land cover using multisensor satellite data. Proceeding of the Map India Conference, (MIC'03), GISdevelopment.net, pp: 1-6. http://www.gisdevelopment.net/technology/rs/pdf/ 109.pdf
49. Thapa, R.T. and Y. Murayama, 2008. Land evaluation for peri-urban agriculture using analytical hierarchical process and geographic information system techniques: A case study of Hanoi. Land Use Policy, 25: 225-239. DOI: 10.1016/j.landusepol.2007.06.004

50. Tivy, J., 1990. Agricultural Ecology. Harlow: Longman Scientific and Technical Publications, New York, ISBN: 0-582-30163-7, pp: 240.

51. Tseng, C.H., C.H.F. Hong and H.L. Chang, 2008. Multiple attributes decision-making model for medical service selection: An AHP approach. J. Qual., 15: 155.

http://joq.iem.yzu.edu.tw/Table_of_Contents/fullpa per/200804/05.pdf

52. Venkata, R.R., 2007. Decision Making in the Manufacturing Environment. 1st Edn., Springer, ISBN: 10: 1846288185, pp: 393.

53. Widtsoe, J.A., 2004. Dry-Farming. The Project Gutenberg ebook No. 4924, pp: 108.

54. Wolfslehner, B., H. Vacik and J. Lexer, 2005. Application of the analytic network process in multi-criteria analysis of sustainable forest management. For. Ecol. Manage., 207: 157-170.

55. Yang, J. and H. Lee, 1997. An AHP decision model for facility location selection. Facilities, 15: 241-254. http://www.emeraldinsight.com/Insight/ViewConte ntServlet;jsessionid=EB7FEFC8CD1D696645078 FA4D91469EE?Filename=Published/EmeraldFull TextArticle/Pdf/0690150905.pdf

56. Yinga, X., Z. Guang-Minga, C. Gui-Qiua, L. Lina, W. Ke-Linc and H. Dao-You, 2007. Combining AHP with GIS in synthetic evaluation of ecoenvironment quality. Ecologic. Model., 209: 97109. DOI: 10.1016/j.ecolmodel.2007.06.007. 